\title{
Substrate Specificity of Glycyrrhizinic Acid Hydrolase
}

\author{
Yasuhiro Sasaki, Toshinobu Morita, Takashi Kuramoto,* \\ Kenji Mizutani, Ryuko IKeda and Osamu Tanaka \\ Institute of Pharmaceutical Sciences, Hiroshima University School of Medicine, \\ Kasumi, Minami-ku, Hiroshima 734, Japan \\ *Maruzen Kasei Co., Ltd., 14703-10 Mukaihigashi-cho, Onomichi 722, Japan
}

Received August 12, 1987

\begin{abstract}
Glycyrrhizinic acid hydrolase produced by Aspergillus niger selectively hydrolyzed the 3-O- $\beta$ D-glucuronide linkage of glycyrrhizinic acid. The substrate specificity of this enzyme was investigated for synthetic glucuronides of aliphatic alcohols as well as natural glucuronide saponins. It was revealed that the glucuronide linkage with low molecular weight alcohols was not cleaved by this enzyme, while the 3-O- $\beta$-D-glucuronide linkage of saponins of oleanolic acid was selectively hydrolyzed. It was also disclosed that both the 4-hydroxyl and carboxyl groups of the glucuronide moiety must be unsubstituted for hydrolysis by this enzyme.
\end{abstract}

Glycyrrhizinic acid (glycyrrhizin, 1) is a wellknown pharmacologically active sweet saponin of Licorice roots. Recently, Muro et al. isolated an enzyme named "glycyrrhizinic acid hydrolase" (GH) from Aspergillus niger GRM3, which was cultivated in a medium containing flowers of Sophora japonica Linne. ${ }^{1)}$ This enzyme selectively hydrolyzed the $3-O-\beta$-D-glucuronide linkage of 1 to give the aglycone, glycyrrhetinic acid (2) and 2-O$\beta$-D-glucuronyl-D-glucuronic acid (4) in a high yield. It is noteworthy that this hydrolytic action was quite different from that of the general $\beta$-glucuronidases, ${ }^{2 \sim 4)}$ which hydrolyze 1 to give 2 and $2 \mathrm{~mol}$ of D-glucuronic acid. Recently, Kanaoka et al. reported that the 3$O-\beta$-D-glucuronide of $\mathbf{2}$ was hydrolyzed by $\mathbf{G H}$, while the $30-O-\beta$-D-glucuronide ester of 2 was not hydrolyzed. ${ }^{5)}$ In order to confirm the scope and limitation of the usefulness of $\mathbf{G H}$ as a novel reagent in the chemistry of natural glycosides, its substrate specificity was investigated.

\section{EXPERIMENTAL}

Synthesis of $\beta$-D-glucuronides (5-8) of methanol, 1-propanol, 2-propanol and cyclohexanol. A mixture of methyl (tri- $O$-acetyl- $\alpha$-D-glucopyanosyl bromide)uronate $(\mathbf{1 3})^{6)}$ $(5.3 \mathrm{~g}), \mathrm{Hg}(\mathrm{CN})_{2}(5.3 \mathrm{~g})$, an anhydrous aglycone alcohol $(10 \mathrm{ml})$ and anhydrous $\mathrm{CH}_{3} \mathrm{CN}(20 \mathrm{ml})$ was stirred at room temperature for $4 \mathrm{hr}$. The mixture was concentrated to dryness and the residue was dissolved in $\mathrm{CHCl}_{3} \cdot \mathrm{After}$ removing the insoluble material by filtration, the filtrate was concentrated to dryness, and to the residue was added $5 \%$ methanolic $\mathrm{KOH}(100 \mathrm{ml})$. The mixture was stirred at room temperature overnight and filtered. The filtrate was deionized with Amberlite MB-3 and then concentrated to dryness. The product was purified by chromatography on silica gel using a solvent of $\mathrm{CHCl}_{3}-\mathrm{MeOH}-\mathrm{H}_{2} \mathrm{O}(6: 4: 1$, homogeneous) and then on Sephadex LH-20 with a $\mathrm{MeOH}$ solvent.

5: a white powder, $[\alpha]_{\mathrm{D}}^{15}-54.4^{\circ}\left(c=1.10, \mathrm{H}_{2} \mathrm{O}\right), 50 \%$ yield from 13, ${ }^{1} \mathrm{H}-\mathrm{NMR}$ (in $\mathrm{D}_{2} \mathrm{O}$ ): $\delta 4.25(1 \mathrm{H}, \mathrm{d}, J=$ $7.3 \mathrm{~Hz}$, anomeric proton). Anal. Found: C, $40.28 ; \mathrm{H}$, $5.90 \%$. Calcd. for $\mathrm{C}_{7} \mathrm{H}_{12} \mathrm{O}_{7}: \mathrm{C}, 40.39 ; \mathrm{H}, 5.81 \%$.

6: a white powder, $[\alpha]_{D}^{15}-72.6^{\circ}\left(c=1.00, \mathrm{H}_{2} \mathrm{O}\right), 22 \%$ yield from $13,{ }^{1} \mathrm{H}-\mathrm{NMR}$ (in $\left.\mathrm{D}_{2} \mathrm{O}\right): \delta 4.37(1 \mathrm{H} \mathrm{d}, J=7.3 \mathrm{~Hz}$, anomeric próton). Anal. Found: $\mathrm{C}, 45.72 ; \mathrm{H}, 6.88 \%$. Calcd. for $\mathrm{C}_{9} \mathrm{H}_{16} \mathrm{O}_{7}: \mathrm{C}, 45.76 ; \mathrm{H}, 6.83 \%$.

7: a white powder, $[\alpha]_{\mathrm{D}}^{15}-46.4^{\circ}\left(c=1.09, \mathrm{H}_{2} \mathrm{O}\right), 38 \%$ yield from $13,{ }^{1} \mathrm{H}-\mathrm{NMR}$ (in $\left.\mathrm{D}_{2} \mathrm{O}\right): \delta 4.40(1 \mathrm{H} \mathrm{d}, J=7.8 \mathrm{~Hz}$, anomeric proton). Anal. Found: C, 45.17; H, 7.20\%. Calcd. for $\mathrm{C}_{9} \mathrm{H}_{16} \mathrm{O}_{7} \cdot 1 / 2 \mathrm{H}_{2} \mathrm{O}: \mathrm{C}, 44.08 ; \mathrm{H}, 7.40 \%$. 
8: a white powder, $[\alpha]_{\mathrm{D}}^{15}-56.9^{\circ}\left(c=0.96, \mathrm{H}_{2} \mathrm{O}\right), 44 \%$ yield from 13, ${ }^{1} \mathrm{H}-\mathrm{NMR}$ (in $\left.\mathrm{D}_{2} \mathrm{O}\right): \delta 4.44(1 \mathrm{H} \mathrm{d}, J=7.8 \mathrm{~Hz}$, anomeric proton). Anal. Found: C, 52.15; H, 7.33\%. Calcd. for $\mathrm{C}_{12} \mathrm{H}_{20} \mathrm{O}_{7}$ : C, $52.17 ; \mathrm{H}, 7.30 \%$.

Synthesis of $\beta$-D-glucuronides $(\mathbf{9 , 1 0}$ and 11) of $l$ - and $d$ menthols and $5 \alpha$-cholestan-3 $\beta$-ol. A mixture of $l$-menthol $(2 \mathrm{~g}), 13(2.5 \mathrm{~g})$ and $\mathrm{CdCO}_{3}(2.5 \mathrm{~g})$ in anhydrous toluene, after removing moisture by co-distillation with toluene, was refluxed for $2 \mathrm{hr}$. After concentration to dryness, the residue was treated with $\mathrm{CHCl}_{3}$ to remove the insoluble material by filtration, and the filtrate was concentrated to dryness, yielding a methyl ester triacetate of 9 as colorless needles, mp $125 \sim 126.5^{\circ} \mathrm{C}$ from $\mathrm{MeOH}-\mathrm{H}_{2} \mathrm{O},[\alpha]_{\mathrm{D}}^{19}$ $-75.0^{\circ}\left(c=0.95, \mathrm{CHCl}_{3}\right), 46 \%$ yield from 13, ${ }^{1} \mathrm{H}-\mathrm{NMR}$ (in $\left.\mathrm{CDCl}_{3}\right): \delta 4.61(1 \mathrm{H} \mathrm{d}, J=8.1 \mathrm{~Hz}$, anomeric proton). Anal. Found: C, $58.02 ; \mathrm{H}, 7.70 \%$. Calcd. for $\mathrm{C}_{23} \mathrm{H}_{36} \mathrm{O}_{10}$ : $\mathrm{C}, 58.46 ; \mathrm{H}, 7.68 \%$. This acetate $(600 \mathrm{mg})$ was saponified with $5 \%$ methanolic $\mathrm{KOH}(50 \mathrm{ml})$ by stirring overnight at room temperature and followed by neutralization with Dowex $50 \mathrm{~W}-\mathrm{X} 8$ to give 9 as a white powder, $[\alpha]_{\mathrm{D}}^{19}-85.3^{\circ}$ $(c=1.09, \mathrm{MeOH}),{ }^{1} \mathrm{H}-\mathrm{NMR}$ (in $\left.\mathrm{C}_{5} \mathrm{D}_{5} \mathrm{~N}\right): \delta 5.06(1 \mathrm{H} \mathrm{d}$, $J=7.3 \mathrm{~Hz}$, anomeric proton).

10 and 11 were synthesized in the same way as with 9 , and elemental analyses were also carried out for the respective crystalline methyl ester triacetates. Methyl ester triacetate of 10: colorless needles, $\mathrm{mp} 182 \sim 182.5^{\circ} \mathrm{C}$ from $\mathrm{MeOH}-\mathrm{H}_{2} \mathrm{O},[\alpha]_{\mathrm{D}}^{19}+2.3^{\circ}\left(c=0.99, \mathrm{CHCl}_{3}\right), 50 \%$ yield from $13,{ }^{1} \mathrm{H}-\mathrm{NMR}$ (in $\mathrm{CDCl}_{3}$ ): $\delta 4.61(1 \mathrm{H} \mathrm{d}, J=7.6 \mathrm{~Hz}$, anomeric proton). Anal. Found: C, $58.52 ; \mathrm{H}, 8.04 \%$. Calcd. for $\mathrm{C}_{23} \mathrm{H}_{36} \mathrm{O}_{10}: \mathrm{C}, 58.46 ; \mathrm{H}, 7.68 \%$.

10: a white powder, $[\alpha]_{\mathrm{D}}^{19}-8.5^{\circ}(c=1.05, \mathrm{MeOH}),{ }^{1} \mathrm{H}$ NMR (in $\left.\mathrm{C}_{5} \mathrm{D}_{5} \mathrm{~N}\right): \delta 5.02(1 \mathrm{H} \mathrm{d}, J=7.1 \mathrm{~Hz}$, anomeric proton). Methyl ester triacetate of 11: colorless needles, mp $177 \sim 180^{\circ} \mathrm{C}$ from EtOH$-\mathrm{H}_{2} \mathrm{O},[\alpha]_{D}^{19}-6.4^{\circ}(c=1.19$, $\mathrm{CHCl}_{3}$ ), 54\% yield from 13, ${ }^{1} \mathrm{H}-\mathrm{NMR}$ (in $\mathrm{CDCl}_{3}$ ): $\delta 4.65$ (1H d, $J=7.8 \mathrm{~Hz}$, anomeric proton). Anal. Found: $\mathrm{C}$, $67.71 ; \mathrm{H}, 9.24 \%$. Caled. for $\mathrm{C}_{40} \mathrm{H}_{64} \mathrm{O}_{10}: \mathrm{C}, 68.15 ; \mathrm{H}$, $9.15 \%$

11: a white powder, ${ }^{1} \mathrm{H}-\mathrm{NMR}\left(\right.$ in $\mathrm{C}_{5} \mathrm{D}_{5} \mathrm{~N}$ ): $\delta 5.99(\mathrm{HH}$ $\mathrm{d}, J=7.5 \mathrm{~Hz}$, anomeric proton). Optical rotation could not be determined due to the low solubility. In this case, a methyl ester triacetate of the $5 \alpha$-cholestan- $3 \beta$-yl $\alpha$-Dglucuronide was obtained from the mother liquor of recrystallization of the methyl ester triacetate of 11 as colorless plates, mp $157 \sim 161^{\circ} \mathrm{C}$ from $\mathrm{CH}_{3} \mathrm{CN}-\mathrm{H}_{2} \mathrm{O}$, $[\alpha]_{\mathrm{D}}^{19}+90.3^{\circ}\left(c=1.03, \mathrm{CHCl}_{3}\right), 2 \%$ yield from $13,{ }^{1} \mathrm{H}-$ NMR (in $\mathrm{CDCl}_{3}$ ): $\delta 5.30(1 \mathrm{H}, \mathrm{d}, J=3.6 \mathrm{~Hz}$, anomeric proton).

Dimethyl ester (3) of 1. A solution of $1(517 \mathrm{mg})$ in $2 \%$ methanolic $\mathrm{HCl}(35 \mathrm{ml})$ was stirred at room temperature for $2 \mathrm{hr}$. To the solution was added $\mathrm{Ag}_{2} \mathrm{CO}_{3}$, and the resulting precipitate was removed by filtration. The filtrate was concentrated to dryness and the residue was chromatographed on silica gel with a solvent of $\mathrm{CHCl}_{3}-\mathrm{MeOH}-$ $\mathrm{H}_{2} \mathrm{O}(40: 15: 2$, homogeneous) to give 3 in a yield of $75 \%$ as a white powder, $[\alpha]_{D}^{19}+55.5^{\circ}(c=1.03, \mathrm{MeOH}) \cdot{ }^{1} \mathrm{H}$ NMR (in $\mathrm{C}_{5} \mathrm{D}_{5} \mathrm{~N}$ ): $\delta 3.71$ and 3.81 ( $3 \mathrm{H}$ each, $\mathrm{s}, \mathrm{OCH}_{3}$ ), ${ }^{13} \mathrm{C}-\mathrm{NMR}$ (in $\mathrm{C}_{5} \mathrm{D}_{5} \mathrm{~N}$ ): $\delta 51.9$ and $52.0\left(1 \mathrm{C}\right.$ each, $\mathrm{OCH}_{3}$ ). Anal. Found: C, 58.30; $\mathrm{H}, 7.79 \%$ Calcd. for $\mathrm{C}_{44} \mathrm{H}_{66} \mathrm{O}_{16} \cdot 3 \mathrm{H}_{2} \mathrm{O}: \mathrm{C}, 58.39 ; \mathrm{H}, 8.02 \%$.

Other substrates. The following natural glucuronide saponins of oleanolic acid (14), which had already been isolated by our research group, were also used as substrates chikusetsusaponins-IV (16), -IVa (17) and -V (ginsenoside-Ro, 18) ${ }^{710}$ from Panax japonicus C. A. Meyer; pseudo-ginsenoside-RT $T_{1}$ (19) from $P$. pseudoginseng Wall. subsp. himalaicus Hara; ${ }^{11}$ hemslosides Mal (20) and $\mathrm{Ma} 2$ (21) from Hemsleya macrosperma C. Y. Wu; ${ }^{12\}}$ stipuleanosides $\mathrm{R}_{1}(\mathbf{2 2})$ and $\mathrm{R}_{2}(\mathbf{2 3})$ from $P$. stipuleanatus $\mathrm{H}$. T. Tsai and K. M. Feng, ${ }^{13}$ ) which were kindly supplied by Dr. T. Yang, Kunming Institute of Botany, Academia Sinica, China.

The ethyl ester (24) of 17 was obtained from an ethanolic extraction of rhizomes of Hemsleya chinensis C. $\mathrm{Y}$. $\mathrm{Wu}$, and the methyl ester (25) of 18 was obtained from a methanolic extraction of rhizomes of Panax japonicus, both of which may have been artifacts formed during the extraction.

The 3-O- $\beta$-D-glucuronide (12) of chenodeoxycholic acid $^{14)}$ was kindly supplied by Dr. Toshifumi Akizawa, Tokyo Medical and Dental University.

Enzyme preparation. An aqueous solution of $\mathbf{G H}$ $(1 \mathrm{U} / \mathrm{ml})$ was prepared (the activity being determined as described previously ${ }^{1 \prime}$ ). Commercial $\beta$-glucuronidase [Sigma No. G-0876 (Lot. No. 73F-0553), 95400 Fishman Units $/ \mathrm{ml}$ ] was used for comparing the activity with that of GH.

Conditions for hydrolysis with $\mathbf{G H}$. To a solution of a

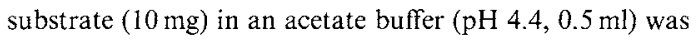
added GH $(0.25 \mathrm{ml})$, and the mixture was incubated at $45^{\circ} \mathrm{C}$. The reaction process was followed by thin-layer chromatography (TLC) on silica gel $\left(\mathrm{CHCl}_{3}-\mathrm{MeOH}-\right.$ $\mathrm{H}_{2} \mathrm{O}$ solvent (6:4:1, homogeneous), $\mathrm{H}_{2} \mathrm{SO}_{4}$ detection) every $15 \mathrm{~min}$.

In the case of $17 \sim 21$, a solution (or suspension) of a substrate $(100 \mathrm{mg})$ and $\mathbf{G H}(0.5 \mathrm{ml})$ in an acetate buffer $(\mathrm{pH} 4.3,5.0 \mathrm{ml})$ was incubated at $45^{\circ} \mathrm{C}$, and the reaction process was followed by similar TLC. When the hydrolysis had been completed, the resulting precipitate was collected by filtration to give a prosapogenin, $\beta$-D-glucopyranosyl oleanolate (15), which was identified by comparing the optical rotation and ${ }^{13} \mathrm{C}-\mathrm{NMR}$ spectrum with those of an authentic sample. The filtrate was chromatographed on DIAION HP-20, successively eluting with $\mathrm{H}_{2} \mathrm{O}$ and $\mathrm{MeOH}$. From the $\mathrm{MeOH}$ eluate, a small amount of 15 was isolated. The $\mathrm{H}_{2} \mathrm{O}$ eluate was deionized by chromatography on Sephadex LH-20, to afford a mono- or oligosaccharide, which was identified by ${ }^{13} \mathrm{C}-\mathrm{NMR}$ spectroscopy (Table I). 


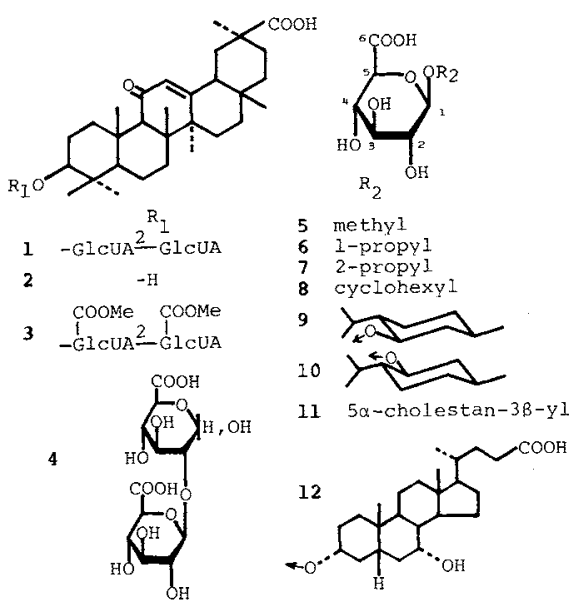

FIG. 1. Glycyrrhizin and Synthetic Glucuronides.

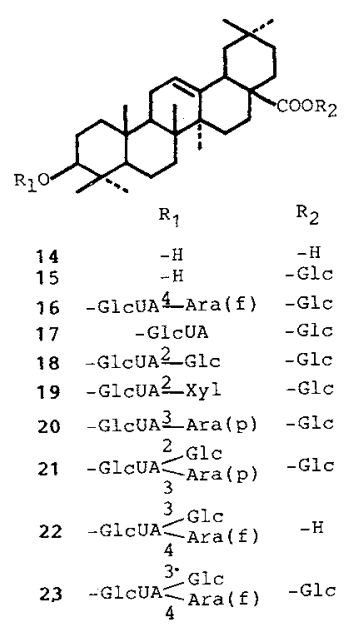

FIG. 2. Natural Glucuronide Saponins.

Glc, $\beta$-D-glucopyranosyl; Xyl, $\dot{\beta}$-D-xylopyranosyl; Ara(p or f), $\alpha$-L-arabino(pyranosyl or furanosyl).

Conditions for hydrolysis with commercial $\beta$-glucuronidase. To a solution of a substrate $(10 \mathrm{mg})$ in an acetate buffer $(\mathrm{pH} 5.0,0.5 \mathrm{ml})$ was added a solution of the $\beta$ glucuronidase $(0.25 \mathrm{ml})$, and the mixture was incubated at $37^{\circ} \mathrm{C}$. The reaction was followed in the way already mentioned.

Due to the very low solubility in the buffer, 11 was not hydrolyzed by either the commercial $\beta$-glucuronidase or GH.

\section{RESULTS AND DISCUSSION}

It was found that the commercial $\beta$-glucuro-
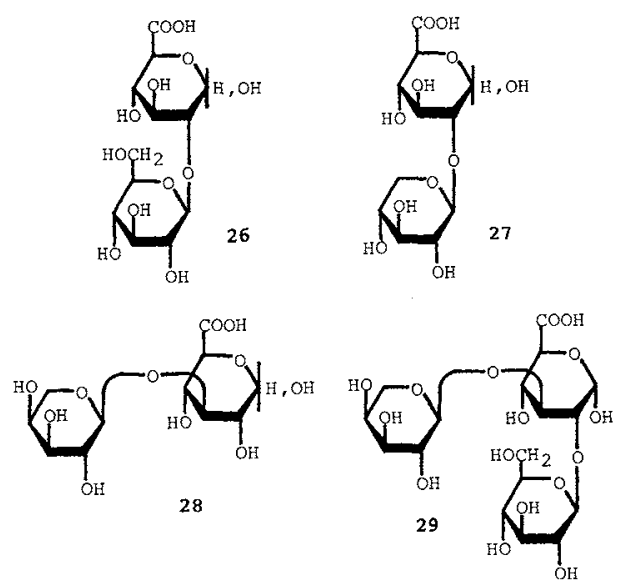

FIG. 3. Oligosaccharides from Natural Glucuronide Saponins.

TAble I. ${ }^{13} \mathrm{C}-\mathrm{NMR}$ Chemical Shifts of OligosaCCHARIDES

\begin{tabular}{|c|c|c|c|c|c|c|c|}
\hline & \multicolumn{2}{|c|}{26} & \multicolumn{2}{|c|}{27} & \multicolumn{2}{|c|}{28} & \multirow{2}{*}{$\frac{29}{\alpha}$} \\
\hline GlcUA & $\alpha$ & $\beta$ & $\alpha$ & $\beta$ & $\alpha$ & $\beta$ & \\
\hline 1 & 92.6 & 95.3 & 92.6 & 95.4 & 92.8 & 96.5 & 92.6 \\
\hline 2 & 81.4 & 81.9 & 81.3 & 82.5 & $72.0^{*}$ & 74.6 & 79.9 \\
\hline 3 & $72.6^{*}$ & 74.2 & $72.4^{*}$ & 74.3 & 82.1 & 84.4 & 80.9 \\
\hline 4 & $72.4^{*}$ & $72.6^{*}$ & $72.4^{*}$ & $72.7^{*}$ & 71.1 & $71.8^{*}$ & 71.3 \\
\hline 5 & $72.2 *$ & 76.8 & $72.7^{*}$ & 76.3 & 73.0 & 74.6 & 72.1 \\
\hline \multirow[t]{2}{*}{6} & 177.6 & 182.2 & & & & & \\
\hline & \multicolumn{2}{|c|}{ Glc } & \multicolumn{2}{|c|}{$\mathrm{XyI}$} & \multicolumn{2}{|c|}{$\operatorname{Ara}(p)$} & Glc \\
\hline 1 & 104.7 & 103.5 & 105.6 & 104.5 & 104.3 & 104.4 & 104.0 \\
\hline 2 & 74 & 4.0 & 74 & .0 & 72 & .0 & 74.1 \\
\hline 3 & 76 & 5.5 & 76 & 3 & 73 & .0 & 76.7 \\
\hline 4 & 70 & .2 & 70 & & 69 & & 70.2 \\
\hline 5 & 76 & 5.3 & 65 & 8 & 67 & .0 & 76.7 \\
\hline \multirow[t]{2}{*}{6} & 61 & 1.3 & - & & - & - & 61.3 \\
\hline & & & & & & & $\operatorname{Ara}(p)$ \\
\hline 1 & & & & & & & 104.2 \\
\hline 2 & & & & & & & 72.1 \\
\hline 3 & & & & & & & 73.3 \\
\hline 4 & & & & & & & 69.2 \\
\hline 5 & & & & & & & 67.0 \\
\hline
\end{tabular}

Chemical shifts are in ppm from TMS (in $\mathrm{D}_{2} \mathrm{O}$ ).

* May be exchanged.

nidase non-selectively hydrolyzed a glucuronide linkage and other glycoside linkages, but not glycosyl ester linkages; $\mathbf{5} \sim \mathbf{1 0}$ and $\mathbf{1 2}$ gave glucuronic acid, $16 \sim 21$ and 23 afforded 15 and the respective component monosaccharides, and 22 afforded 14 and the component monosaccharides. 
It has already been reported that $p$-nitrophenyl $\beta$-D-glucuronide and phenolphthalein $\beta$-D-glucuronide, which have been used as the standard substrates of general $\beta$-glucuronidase, were not hydrolyzed by $\mathbf{G H} .{ }^{1)}$ In the present study, it was revealed that $\mathbf{G H}$ does not cleave glucuronide linkages with small-size aliphatic alcohols; no hydrolysis by GH was observed with $\mathbf{5} \sim \mathbf{1 0}$ even after $24 \mathrm{hr}$ of incubation, while by incubating with $\mathbf{G H}, 12$ was slowly hydrolyzed to give chenodeoxycholic acid and glucuronic acid.

On the other hand, $\mathbf{1 8}$ was rapidly hydrolyzed by $\mathbf{G H}$ to give a prosapogenin (15) and $\quad 2-O-\beta$-D-glucopyranosyl-D-glucuronic acid (26) quantitatively within $30 \mathrm{~min}$. Selective hydrolysis of the glucuronide linkage by $\mathbf{G H}$ was also observed with 17 and $19 \sim 21$, affording the common prosapogenin 15 together with D-glucuronic acid from 17, 2-O- $\beta$ D-xyopyranosyl-D-glucuronic acid (27) from 19, 3- $O-\alpha-\mathrm{L}$-arabinopyranosyl-D-glucuronic acid (28) from 20, and 2- $O-\beta$-D-glucopyranosyl-(3- $O-\alpha-\mathrm{L}$-arabinopyranosyl)- $\alpha$-D-glucuronic acid (29) from 21. It is notable that in $17 \sim 21$, the 4-hydroxyl group of the glucuronide moiety is unsubstituted.

In contrast to these glucuronides, 16, 22 and 23 (in which the 4-hydroxyl group of the glucuronide moiety is glycosylated) were not hydrolyzed by GH. When the carboxyl group of the glucuronide moiety was esterified, GH could not hydrolyze the glucuronide linkage; 24, 25 and 3 were recovered unchanged by incubating with $\mathbf{G H}$.

These results indicate that for the hydrolysis of a $\beta$-D-glucuronide linkage by $\mathbf{G H}$, both the 4-hydroxyl group and the carboxyl groups in a glucuronide moiety must be free. This high substrate specificity observed in the present study is significant in the application of this enzyme to chemical studies on natural glucuronide saponins.

\section{REFERENCES}

1) T. Muro, T. Kuramoto, K. Imoto and S. Okada, Agric. Biol. Chem., 50, 687 (1986).

2) G. A. Levy and C. A. March, "The Enzyme," 2nd Ed., Vol. IV, ed. by P. D. Boyer, Academic Press Inc., New York, 1960, p. 397.

3) W. H. Fishman, "Advances in Enzymology," Vol. XVI, ed. by F. F. Nord, Interscience Publishers Inc., New York, 1955, p. 361.

4) A. Koshiro, A. Sawa and S. Oie, Yamaguchi Igaku, 32, 605 (1983).

5) M. Kanaoka, S. Yano, H. Kato and T. Nakada; Chem. Pharm. Bull., 34, 4978 (1986).

6) G. N. Bollenback, J. W. Long, D. G. Benjamin and J. A. Lindquist, J. A. C. S., 77, 3310 (1955).

7) N. Kondo and J. Shoji, Yakugaku Zasshi, 88, 325 (1968).

8) N. Kondo, J. Shoji, N. Nagumo and N. Komatsu, Yakugaku Zasshi, 89, 846 (1969).

9) N. Kondo, Y. Marumoto and J. Shoji, Chem. Pharm. Bull., 19, 1103 (1971).

10) T.-D. Lin, N. Kondo and J. Shoji, Chem. Pharm. Bull., 24, 253 (1976).

11) O. Tanaka, T. Morita, R. Kasai, J. Kinouchi, S. Sanada, Y. Ida and J. Shoji, Chem. Pharm. Bull, 33, 2323 (1985).

12) R.-L. Nie, T. Morita, R. Kasai, J. Zhou, C.-Y. Wu and O. Tanaka, Planta Medica, 50, 322 (1984).

13) C. R. Yang, Z. D. Jiang, J. Zhou, R. Kasai and O. Tanaka, Acta Botanica Yunnanica, 7, 103 (1985).

14) J. Goto, K. Suzaki and T. Nambara, Chem. Pharm. Bull., 28, 1258 (1980). 